\title{
Population census and age category character of Stump-tailed macaque, Macaca arctoides, in Northern Peninsular Malaysia
}

\author{
ABD RAHMAN SYAMIL ${ }^{1}$, ABD RAHMAN MOHD-RIDWAN ${ }^{2,3}$, MOHD ARIF AMSAH $^{1}$, \\ MUHAMMAD ABU BAKAR ABDUL-LATIFF ${ }^{4}$, BADRUL MUNIR MD-ZAIN ${ }^{2,5, \bullet}$ \\ ${ }^{1}$ Perlis Nature and Wildlife. 01000, Kangar, Perlis, Malaysia \\ ${ }^{2}$ School of Environmental and Natural Resource Sciences, Faculty of Science and Technology, Universiti Kebangsaan Malaysia, 43600, Bangi, Selangor, \\ Malaysia. Tel.: +60-389-213200, `email: abgbadd@ukm.edu.my, abgbadd1966@yahoo.com \\ ${ }^{3}$ Centre for Pre-University Studies, Universiti Malaysia Sarawak. 94300, Kota Samarahan, Sarawak, Malaysia \\ ${ }^{4}$ Centre of Research for Sustainable Uses of Natural Resources (CoR-SUNR), Faculty of Applied Sciences and Technology, Universiti Tun Hussein Onn \\ Malaysia (Pagoh Campus). 84000, Muar, Johor, Malaysia \\ ${ }^{5}$ Bukit Merah Orang Utan Island Foundation. Bukit Merah, 34400, Perak, Malaysia
}

Manuscript received: 29 July 2019. Revision accepted: 7 August 2019.

\begin{abstract}
Syamil AR, Mohd-Ridwan AR, Amsah MA, Abdul-Latiff MAB, Md-Zain BM. 2019. Population census and age category character of Stump-tailed macaque, Macaca arctoides, in Northern Peninsular Malaysia. Biodiversitas 20: 2446-2452. Macaca arctoides is reported to be distributed only in the northern part of Malay Peninsula. Intensive scientific observations have never been carried out before on this neglected macaque in the northern range. Thus, in this article, an estimation of population data on the Malaysian stump-tailed macaques that were found in Wang Kelian forest areas in Perlis State Park, Malaysia is presented. Intensive field observations were conducted from Sept 2018 to January 2019 with scanning sampling. The study revealed a total of 171-176 stump-tailed macaques, consisting of 44 (25\%) adult males, 28 (16\%) adult females, 19-22 (11\%) sub-adult males, 16-19 (10\%) subadult females, 43 (25\%) juveniles, and 21-23 (13\%) infants. Two main groups were observed, which were the Nomad and the Batat groups. Their ranging areas appear to sometimes overlap each other, while some Nomad members were observed in the Batat group. The age structure can be differentiated through body size and pelage coloration. The stump-tailed macaque populations in Wang Kelian are sensitive to human presence, while their habitat area is threatened by human illegal poaching activities. More conservation efforts are needed to conserve this neglected macaque from local extinction.
\end{abstract}

Keywords: Macaca arctoides, stump-tailed macaque, beruk kentoi, Wang Kelian, Malaysian primates

\section{INTRODUCTION}

The Stump-tailed macaque, Macaca arctoides (Geoffroy, 1831), or locally known as beruk kentoi in Malaysia, is an understudied primate group opposed to its sister clade, M. fascicularis (Abdul-Latiff et al. 2014a; 2014b; 2014c; Ruslin et al. 2019). In Malaysia, the stumptailed macaque is restricted to the state of Perlis in Northern Peninsular Malaysia (Md-Zain et al. 2010a; Roos et al. 2014). Their distribution covers Cambodia, southwestern China, northeastern India, Laos, northwestern Peninsular Malaysia, northern Myanmar, Thailand, and Vietnam (Htun et al. 2008). In India, the stump-tailed macaque was reported to be critically endangered, while in Bangladesh, it was reported to be locally extinct (Molur et al. 2003). The stump-tailed macaque has various pelage colors in shades of red, brown, and black (Fooden 1990; Koyabu et al. (2008). Based on pelage color and geographical distribution, Lekagul and McNeely (1988) classified M. arctoides into two subspecies. Northern populations from southern China to the northern mountainous areas of Thailand with bright brown pelage represent $M$. a. arctoides, and southern populations that inhabit the lower latitudes of Southeast Asia with black coloring represent M. a. melanota; however, different color variants in $M$. arctoides have been observed to coexist within the same populations of southern (Fooden 1990) and western Thailand (Malaivijitnond and Hamada 2005) and hence have not been classified as subspecies (Fooden 1990; Koyabu et al. 2008).

Stump-tailed macaques are uniquely classified as both arboreal and terrestrial species (Smith et al. 2008) with claims that they spend most of their time foraging and traveling on the forest floor (Fooden 1990). Although still unknown, Srivastava (1999) estimated that the home range for this species is several square kilometers and that they live in multimale-multifemale social groups with troop sizes varying from 10 to 60 individuals (Fooden 1990). These social groups are female-bonded, with the core of the group consisting of related females that develop preferential relationships and support each other during conflicts (Thierry 2007). In Perlis, both M. arctoides and M. fascicularis are present in Wang Kelian (Jayaraj et al. 2013). It was assumed there is no interspecific association among them as observed by Malaivijitnond and Hamada (2005) at Wat Tham Khao Daeng. In addition, our preliminary observation also indicated that the third Malaysia macaque species, M. nemestrina, also dwells sympatrically in Perlis State Park forest areas. 
The current population status of $M$. arctoides in Southeast Asia is largely based on old records dating from the 1980s. Based on previous studies 15 years ago, $M$. arctoides populations were critically threatened in India, declining in Myanmar, stable in Thailand, and declining rapidly in China and Vietnam (Molur et al. 2003); however, in Malaysia, there are no updated data to classify the populations as stable, declining, or highly threatened. The first confirmed sighting was encountered by Sharma (1994) and later by Kamarudin (2000) to document the stump-tailed macaque in Perlis. Thus, this article presents the first population census of $M$. arctoides in Perlis, Malaysia, as well as the age structure category of the Wang Kelian populations in the Perlis State Park forest areas.

\section{MATERIALS AND METHODS}

\section{Study site}

Perlis State Park (PSP) is situated in the northernmost area of Peninsular Malaysia (Figure 1). It is located at the Nakawan range, which is the longest limestone hill in Malaysia (Herman et al. 2013). The range stretches from Kuala Perlis to Southern Thailand. The PSP forms a transfrontier protected area with the Thaleban National Park in Thailand (Idris and Abang 2011). The park area is 5,015 ha and covers Mata Ayer Reserve (2,156 ha) and Wang $\mathrm{Mu}$ Forest Reserve (2,859 ha) (Rahimatsah and Kasim 2002). This state park is vegetated by a semideciduous forest influenced by the northern and dry monsoon elements of the Thai-Burmese region that distinguish flora in Perlis from other parts of Peninsular Malaysia (Mathew and Sharma 1994).

\section{Population census and age structure category}

The $M$. arctoides population was surveyed in the Wang Kelian areas of PSP using a census walk and also by vehicle to locate and count individuals (Ampeng and MdZain 2012). The study sites were surveyed by the direct sighting, movement, and the vocalization of the macaque. The observation was conducted from 9 am to $7 \mathrm{pm}$ and involved its main ranging areas including the observatory tower, the oil palm plantation and adjacent hillside forest. Once a group of $M$. arctoides was encountered, data was collected using the ad libitum sampling method. No transect has been made due to physical condition of ranging areas that located on a slope of Nakawan range. The group size and age-sex class of groups were observed (Fittinghoff 1972; Md-Zain et al. 2010b). The stump-tailed macaque groups were classified according to the unique characteristics of each individual, body size, and sex (Hamada et al. 2005). To obtain accurate data, the group counting and age structure was confirmed by photo analyses.

\section{RESULTS AND DISCUSSION}

\section{Population structure}

The stump-tailed macaques of Wang Kelian are comprised of two main groups, the Nomad and the Batat groups (Table 1), with a total number of approximately 171-176 individuals. Of these, $44(25 \%)$ were adult males, $28(16 \%)$ adult females, 19-22 (11\%) sub-adult males, 16$19(10 \%)$ sub-adult females, 43 (25\%) juveniles, and 21-23 $(13 \%)$ infants. These results indicate that the stump-tailed macaques of Wang Kelian belong to multimale and multifemale groups, as was previously also described by Richter et al. (2009) for the stump-tailed macaques of the southern Thailand population. This social organization is also similar to its sister taxon, Macaca fascicularis (MdZain et al. 2010b). Juveniles also dominated in the agestructure category in Wang Kelian, as they represented $25 \%$. M. arctoides has been reported to be a year-round breeder (Smith 1984); however, in captivity, stump-tailed macaques breeding was observed to be seasonal (Solanksi 2013). Thus, the stump-tailed macaque habitat in Wang Kelian can sustain a population for large numbers of juveniles. Richter et al. (2009) in their stump-tailed macaque surveyed near the Wat Khuha Santayaram monastery in Nakhon Si Thammarat Province, southern Thailand, were also found to have high juvenile numbers. Their focal group consisted of 68 individuals with seven adult males, two subadult males, 15 adult females, 33 juveniles, and 11 infants.

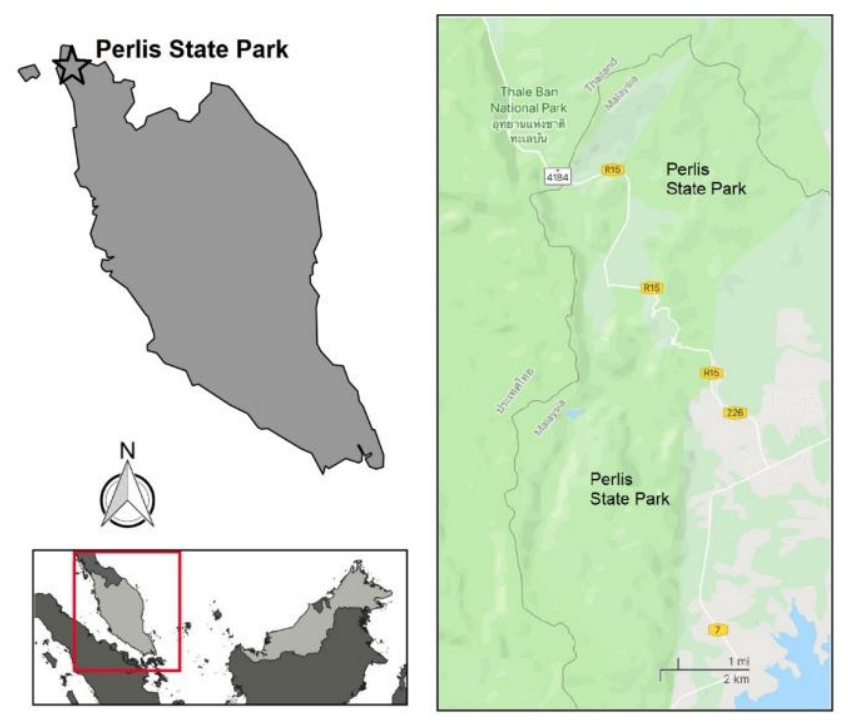

Figure 1. Map of Perlis State Park, Malaysia

Table 1. Wang Kelian stump-tailed macaque group size and composition, Perlis State Park, Malaysia

\begin{tabular}{lccc}
\hline & $\begin{array}{c}\text { Nomad } \\
\text { group }\end{array}$ & $\begin{array}{c}\text { Batat } \\
\text { group }\end{array}$ & Total \\
\hline Adult male & 39 & 5 & $44(25 \%)$ \\
Adult female & 24 & 4 & $28(16 \%)$ \\
Sub-adult male & 14 & $5-8$ & $19-22(11 \%)$ \\
Sub-adult female & 12 & $4-7$ & $16-19(10 \%)$ \\
Juvenile & 34 & 9 & $43(25 \%)$ \\
Infant & 16 & $5-7$ & $21-23(13 \%)$ \\
Total & 139 & $32-37$ & $171-176$ \\
\hline
\end{tabular}


For ranging areas, the Nomad group sometimes overlaps with the Batat group. Due to the wide range of their areas, the two groups sometimes share the same sympatric ranging area in the oil palm and slope areas of PSP forest (Figure 2). The Nomad group has also been observed, ranging around the main road and near the observation tower. The Nomad group consisted of a huge membership of 139 individuals. The number of individuals and age-structure class in detail were also estimated using photography captured during observations of the Nomad group. The group was counted from the first individual to the last individual crossing roads (Figure 2).

The number of Batat group members was not as high as the Nomad group. The number of members in this group was found to differ from several censuses to about 32-37 individuals. This was because some members of the Nomad group sometimes joined the Batat group during ranging. This was not surprising because some of the macaque species are known to have a fission-fusion society social system that allows members to move from one group to another (Ménard and Vallet 1993). Another possible group (Malut) was encountered on the only first brief sighting in nearby PSP headquarters forest with no troop photos available. This group was extremely difficult to detect despite repeated observations. This may be due to the fact that the Malut ranging area also covers Thailand sites where the group commute in border areas of Malaysia and Thailand. Since the preliminary observation began in July 2017, Wang Kelian stump-tailed macaques have been highly sensitive to human presence. These macaque groups were highly difficult to detect and disappeared for several days before reappearing in the observation area. The process of habituation to observers also required time before the intensive study began, and the group began to familiarize themselves with the observer vehicle. Once the census was conducted, it was already accustomed to observer presence (Ampeng and Md-Zain 2007). The stump-tailed macaques of Wang Kelian were observed to be terrestrial. Individuals walked quadrupedally on the ground except on some occasions when they were found to climb oil palm and ficus trees. Several social activities, such as grooming, were also observed to be arboreal.

\section{Age structure and individual characteristics}

From Sept 2018 to January 2019, observations of two main stump-tailed macaque groups were conducted. With different numbers of individuals in the groups, group members were also observed to characterize age-structure categories with their morphological characteristics (Table 2, Figures 3, 4).
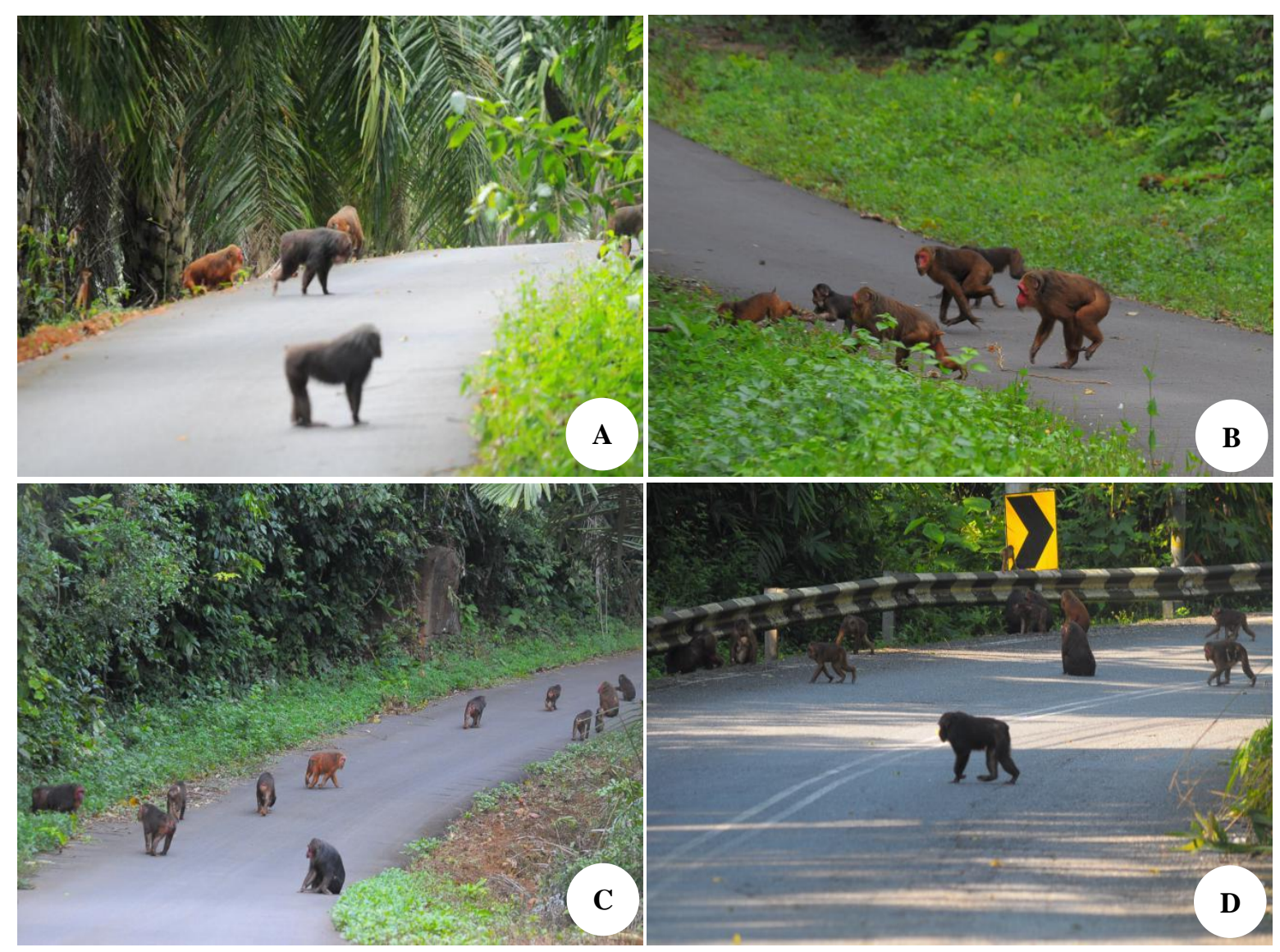

Figure 2. Ranging areas of stump-tailed macaque in Wang Kelian, Perlis State Park, Malaysia 

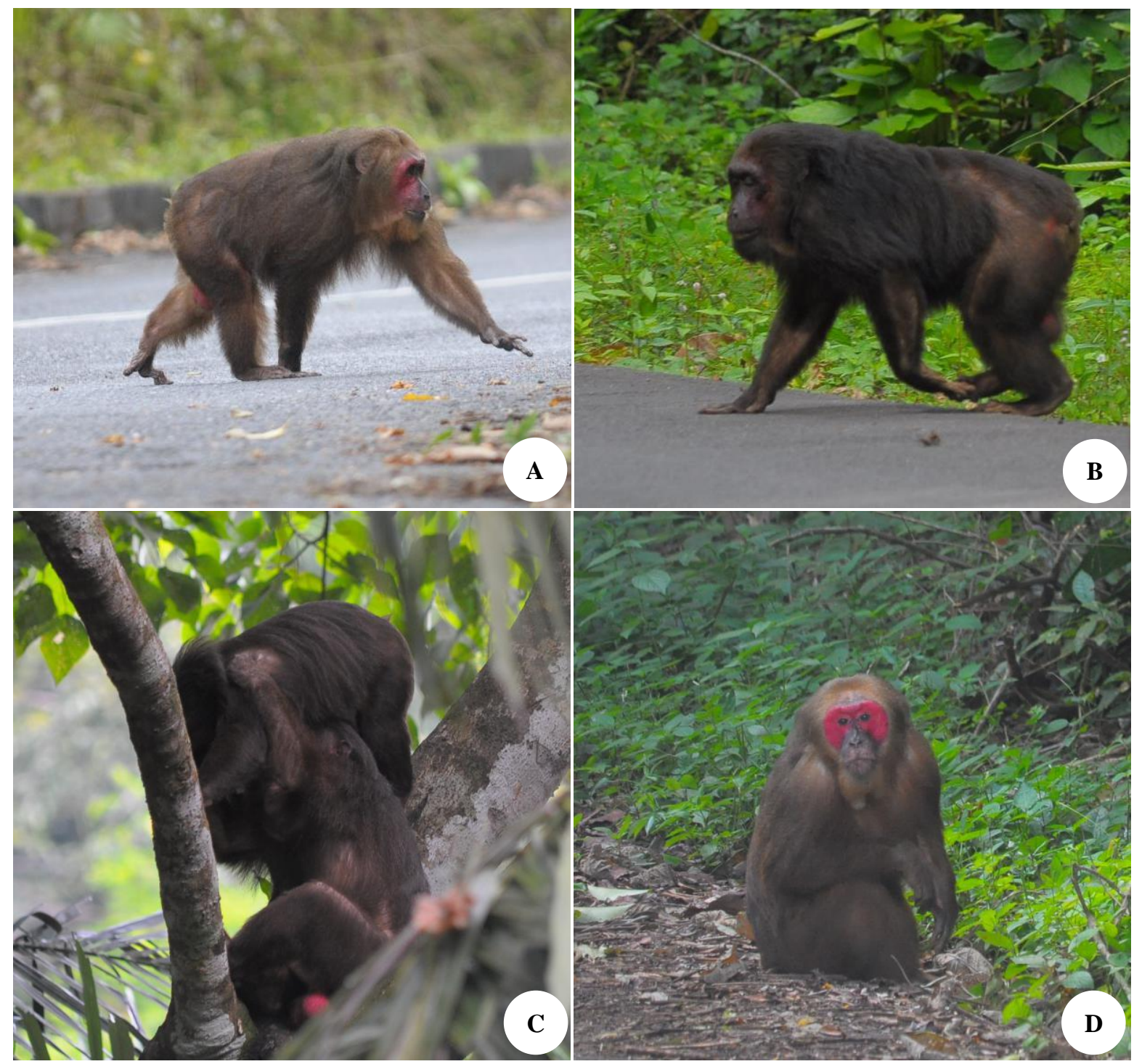

Figure 3. Adult male stump-tailed macaque of Wang Kelian: A. Koko, B. Itam, C. Abu, D. Topeng

Table 2. Individual stump-tailed macaques frequently seen in Wang Kelian, Perlis State Park, Malaysia

\begin{tabular}{lll}
\hline Sex & Nomad group & Batat group \\
\hline Adult male & Koko (Dominant) & Abu (Dominant) \\
Adult male & Itam & Topeng \\
Adult female & Che Puteh & Embun \\
Subadult male & Kacak & \\
Subadult male & Rongak & \\
Subadult male & Kacang & \\
\hline
\end{tabular}

Among the main external characteristics of Wang Kelian adult males are a large size with a thick and long pelage in dark coloration (Hill 1974; Fooden 1990). Koko was observed to be dominant and to lead the Nomad group. Itam is an adult male that was also observed to have a higher ranking in the Nomad group. In addition, Abu was observed to be a dominant male leading the Batat group.
Topeng was another adult male in the Batat group. Both $\mathrm{Abu}$ and Topeng were observed guarding the Batat group during group ranging. Subadult males are smaller in size compared to adult males with light coloration. In this category, Kacak was more prominent with his attractive morphological appearance (Figure 4). The subadult pelage is chestnut brown and frayed (Roonwal and Mohnot 1977; Napier and Napier 1967).

Sexual dimorphism was also observed as adult females have smaller body sizes than adult males. Some adult female individuals were observed caring for infants. Infants were found clinging to their mothers when groups crossed roads. Che Puteh was an adult female that was clearly observed due to her appearance in pelage color. Most of her pelage had begun to turn white. Some adult members were also found to have lost their teeth due to age factors. The subadult female category had more slender bodies compared to adult females. The members of this category 
always ranged together (Figure 4). The adult pelage on the chest and abdomen were scattered and reddish-brown, which is a characteristic that distinguishes them from other macaque species (Fooden 1990). With increasing age, the pelage coloration becomes darker, and some pelage becomes gray (Napier and Napier 1967). In addition, variation in pelage coloration is associated with different populations of stump-tailed macaques, according to
Koyabu et al. (2008). The main infant features were white pelage and small size; however, one unique characteristic is the pelage color of an infant of white cream (Bertrand 1969; Fooden 1990). The infant was always observed with its mother. The juvenile size was relatively modest. At this stage, the pelage color has become darker. Juveniles were observed displaying play behaviors.
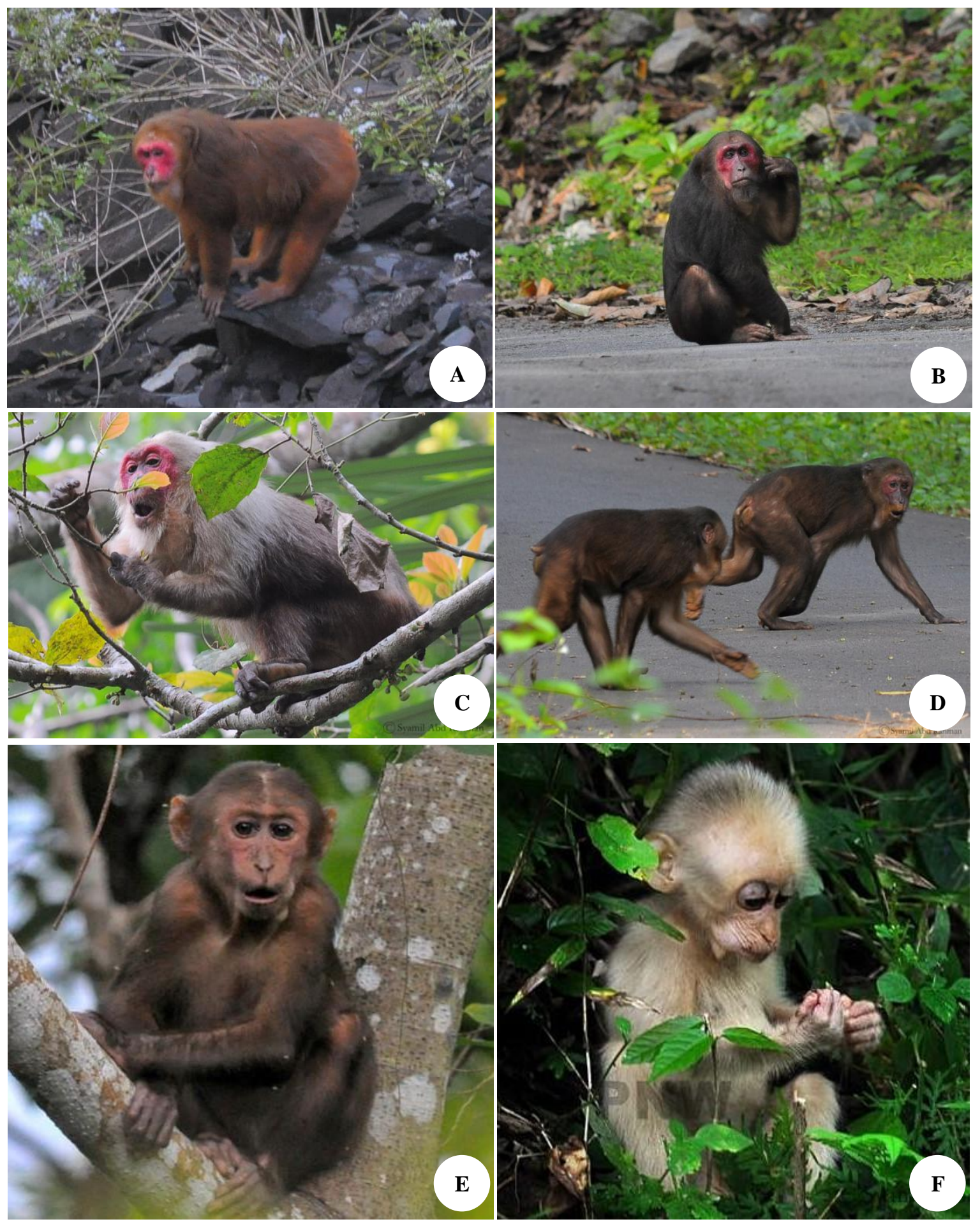

Figure 4. Sub-adult male. A. Kacak, B. Adult female, C. Cik Puteh, D. Sub-adult female, E. Juvenile, F. Infant 
In conclusion, This research study provided the population information of Wang Kelian of two main stump-tailed macaque groups in the only distribution site of $M$. arctoides known in Malaysia. Indeed, the research findings are highly important in contributing to the knowledge of Malaysian primate diversity, especially the Cercopithecine. Stump-tailed macaques have been completely neglected in scientific observations compared to its sister taxa, M. fascicularis, and M. nemestrina. This species is difficult to follow as its distribution covers both ranging areas at the Malaysia-Thailand border, and poaching activities in this area could cause observers to be less secure. Several attempts were made to install camera traps; however, the preliminary collected data on camera traps indicated that the stump-tailed macaques attempted to damage the equipment. The camera trap method will be useful in ensuring a current and monthly population census of the $M$. arctoides. Future ecological, behavioral, and genetic studies are suggested for Wang Kelian stump-tailed macaques. These studies should include feeding ecology, daily activity patterns, and further population genetic studies. The stump-tailed macaque population is threatened by human presence and poaching activities in the Wang Kelian ranging areas. Thus, conservation efforts are needed by local authorities to ensure that the Wang Kelian population is well-conserved.

\section{ACKNOWLEDGMENTS}

We thank the Department of Wildlife and National Park (DWNP) Peninsular Malaysia especially YBhg. Dato' Abdul Kadir bin Abu Hashim, Director General of the DWNP; Mr. Petra Sulai, Director of Department of Wildlife and National Parks (Perlis). We are deeply indebted to Perlis Nature and Wildlife, and Universiti Kebangsaan Malaysia for providing necessary facilities and assistance during field observation. The research was conducted under research permit approved by the Department of Wildlife and National Parks, Malay Peninsula (JH/100 Jld 21). This research was supported by Universiti Kebangsaan Malaysia Grants AP-2015-004 and UKM-GUP-2017-087. Author's contribution: Syamil AR and Amsah MA conducted field observation. Md-Zain BM and Mohd-Ridwan AR visited study sites for species and age category confirmation. Md-Zain BM, Mohd-Ridwan $\mathrm{AR}$, and Abdul-Latiff MAB wrote the article.

\section{REFERENCES}

Abdul-Latiff MAB, Ampeng A, Yaakop S, Md-Zain BM. 2014a. Phylogenetic relationships of Malaysia's pig-tailed macaque Macaca nemestrina based on D-loop region sequences. AIP Conf Proc 1614: $772-776$

Abdul-Latiff MAB, Ruslin F, Faiq H, Hairul MS, Rovie-Ryan JJ, AbdulPatah P, Yaakop S, Md-Zain BM. 2014b. Continental monophyly and molecular divergence of Peninsular Malaysia's Macaca fascicularis fascicularis. Biomed Res Int 2014: 897682.

Abdul-Latiff MAB, Ruslin F, Vun VF, Mohd-Hashim A, Rovie-Ryan JJ, Abdul-Patah P, Lakim M, Roos C, Yaakop S, Md-Zain BM. 2014a. Phylogenetic relationships of Malaysia's long-tailed macaques,
Macaca fascicularis, based on Cytochrome $b$ sequences. ZooKeys 407: 121-139.

Ampeng A, Md-Zain BM. 2007. A short note on methodology of detecting leaf monkeys (Presbytis melalophos chrysomelas and Trachypithecus cristatus) in Samunsam Wildlife Sanctuary, Sarawak. J Wildlife Parks 24: 7-9.

Ampeng A, Md-Zain BM. 2012. Ranging patterns of critically endangered colobine, Presbytis chrysomelas chrysomelas. The Sci World J 2012: 594382.

Bertrand M. 1969. The behavioural repertoire of the stump-tailed macaque: A descriptive and comparison study. Switzerland: S. Karger AG.

Fittinghoff NA. 1972. Macaca fascicularis on eastern Borneo: ecology, demography, social behaviour and social organization in relation to a refuging habitat. [Dissertation]. University of California, Los Angeles, CA.

Fooden J. 1990. The bear macaque, Macaca arctoides: a systematic review. J Hum Evol 19: 607-686.

Hamada Y, Hadi I, Urasopon N, Malaivijitnond S. 2005. Preliminary report on yellow long-tailed macaques (Macaca fascicularis) at Kosumpee Forest Park, Thailand. Primates 46 (4): 269-273.

Herman S, Ahmad S, Ramachandran S, Rusli M. 2013. Length of stay of discrete outdoor recreational experiences of Perlis State Park. Malaysian Forester 76 (2): 133-139.

Hill WCO. 1974. Primates: comparative anatomy and taxonomy VII Cynopithecinae: Cercocebus, Macaca, Cynopithecus. Edinburg: Edinburgh University Press.

Htun S, Timmins RJ, Boonratana R, Das J. 2008. Macaca arctoides. The IUCN Red List of Threatened Species 2008: e.T12548A3354519. http://dx.doi.org/10.2305/IUCN.UK.2008.RLTS.T12548A3354519.e n. Downloaded on 16 July 2019.

Idris MIB, Abang F. 2011. New distributional record of Hypochrosis cryptopyrrhata Walker, 1862 (Geometridae: Ennominae) from Peninsular Malaysia. Trop Nat Hist 11 (1): 71-73.

Jayaraj VK, Daud SHM, Azhar M-I, Sah SAM, Mokhtar SI, Abdullah MT. 2013. Diversity and conservation status of mammals in Wang Kelian State Park, Perlis, Malaysia. Check List 9 (6): 1439-1448.

Kamarudin H. 2000. A note on the sighting of stump-tailed macaques (Macaca arctoides) in Perlis, Malaysia. Malay Nat J 54 (4): 373-374.

Koyabu DB, Malaivijitnond S, Hamada Y. 2008. Pelage color variation of Macaca arctoides and its evolutionary implications. Int J Primatol 29: 531-541.

Lekagul B, McNeely JA. 1988. Mammals of Thailand. Darnsutha Press, Bangkok.

Malaivijitnond S, Hamada Y. 2005. A new record of stump-tailed macaques in Thailand and the sympatry with long-tailed macaques. The Nat Hist J Chulalongkorn University 5 (2): 93-96.

Mathew D, Sharma DSK. 1994. Biodiversity in Peninsular Malaysia transfrontier forests: A case study at Mata Ayer Forest Reserve and the proposed Bukit Wang Mu Forest Reserve, Perlis. Pp: 123-144 In: Haron AH et al (Eds) Proceedings of the ASEAN seminar on the management and conservation of biodiversity. ASEAN Institute of Forest Management.

Md-Zain BM, Mohamad M, Ernie-Muneerah MA, Ampeng A, Jasmi A, Lakim M, Mahani MC. 2010a. Phylogenetic relationships of Malaysian monkeys, Cercopithecidae, based on mitochondrial cytochrome c sequences. Genet Mol Res 9 (4): 1987-1996.

Md-Zain BM, Sha`ari NA, Mohd-Zaki M, Ruslin F, Idris NI, Kadderi MD, Idris WMR. 2010b. A comprehensive population survey and daily activity budget on long tailed macaques of Universiti Kebangsaan Malaysia. J Biol Sci 10 (7): 608-615.

Ménard N, Vallet D. 1993. Population dynamics of Macaca sylvanus in Algeria: an 8 years study. Am J Primatol 30 (2): 101-118.

Molur S, Brandon-Jones D, Dittus W, Eudey A, Kumar A, Singh M, Feeroz MM, Chalise M, Priya P, Walker S. 2003. The status of South Asian primates: conservation assessment and management plan (CAMP) workshop report. Zoo Outreach Organisation/CBSG-South Asia. Coimbatore, India.

Napier J.R. Napier PH. 1967. A handbook of living primates: morphology, ecology and behaviour of nonhuman primates. Academic Press inc., London.

Rahimatsah A, Kasim O. 2002. The administration and management of Perlis State Park. In: Faridah-Hanum L, Osman K, Yussof AR, Latiff A (eds.). Forest Department of Perlis, Kangar, Perlis, Malaysia. 
Richter C, Mevis L, Malaivijitnond S, Schülke O, Ostner J. 2009. Social relationships in free-ranging male Macaca arctoides. Intl J Primatol 30 (4): 625-642.

Roos C, Boonratana R, Supriatna J, Fellowes JR, Groves CP, Nash SD, Rylands AB, Mittermeier RA. 2014. An updated taxonomy and conservation status review of Asian primates. Asian Primates J 4: 238.

Ruslin F, Matsuda I, Md-Zain BM. 2019. The feeding ecology and dietary overlap in two sympatric primate species, the long-tailed macaque (Macaca fascicularis) and dusky langur (Trachypithecus obscurus obscurus), in Malaysia. Primates 60 (1): 41-50.

Sharma DSK. 1994. First confirmed sighting of the stump-tailed macaque (Macaca arctoides) in Peninsular Malaysia. Malay Nat J 47 (3): 319 320 .
Smith AT, Xie Y, Hoffmann RS, Lunde D, MacKinnon J, Wilson DE, Chris Wozencraft W. 2008. A guide to the mammals of China. Princeton University Press, Princeton, NJ.

Smith EO. 1984. Non-seasonal breeding patterns in stump-tailed macaque (Macaca arctoides). Primates 25: 117-122.

Solanki GS. 2013. Births in captive stump-tailed macaques (Macaca arctoides). Folia Primatol 84 (6): 394-404

Srivastava A. 1999. Primates of northeast India. Mega Diversity Press, Bikaner, India.

Thierry B.2007. Unity in diversity: Lessons from macaque societies. Evol Anthropol 16: 224-238. 